University of Nebraska - Lincoln

DigitalCommons@University of Nebraska - Lincoln

Faculty Publications: Department of

Entomology

Entomology, Department of

1991

Potential of Starch Encapsulated Semiochemical-Insecticide

Formulations for Adult Corn Rootworm (Coleoptera:

Chrysomelidae) Control

\author{
Thomas J. Weissling \\ University of Nebraska-Lincoln, tweissling2@unl.edu \\ Lance J. Meinke \\ University of Nebraska-Lincoln, Imeinke1@unl.edu
}

Follow this and additional works at: https://digitalcommons.unl.edu/entomologyfacpub

Part of the Entomology Commons

Weissling, Thomas J. and Meinke, Lance J., "Potential of Starch Encapsulated Semiochemical-Insecticide Formulations for Adult Corn Rootworm (Coleoptera: Chrysomelidae) Control" (1991). Faculty Publications: Department of Entomology. 325.

https://digitalcommons.unl.edu/entomologyfacpub/325

This Article is brought to you for free and open access by the Entomology, Department of at DigitalCommons@University of Nebraska - Lincoln. It has been accepted for inclusion in Faculty Publications: Department of Entomology by an authorized administrator of DigitalCommons@University of Nebraska - Lincoln. 


\title{
Potential of Starch Encapsulated Semiochemical-Insecticide Formulations for Adult Corn Rootworm (Coleoptera: Chrysomelidae) Control
}

\author{
THOMAS J. WEISSLING AND LANCE J. MEINKE \\ Department of Entomology, University of Nebraska, \\ Lincoln, Nebraska 68583-0816
}

\begin{abstract}
J. Econ. Entomol. 84(2): 601-609 (1991)
ABSTRACT Field and laboratory experiments were conducted from 1987 through 1989 to determine if plant-derived semiochemicals and carbamate insecticides, encapsulated in starch-borate (SBM) and pregelatinized-starch (PGM) matrices, could be used to attract and kill corn rootworm (Diabrotica spp.) beetles. D. virgifera virgifera LeConte adults were concentrated in plots within a corn (Zea mays L.) field, following application of SBM granules formulated with semiochemicals and carbaryl. However, resulting mortality was low even though beetles were observed feeding on the granules. Low mortality levels appear to have been caused by a loss of carbaryl during the formulation process. Laboratory assay results indicated that carbaryl, methomyl or carbofuran formulated in the PGM effectively killed $D$. virgifera adults but only SBM granules formulated with carbofuran provided acceptable mortality. PGM semiochemical-insecticide granules placed in traps killed Diabrotica spp. over time in field corn. D. v. virgifera and D. undecimpunctata howardi Barber mortality in plots treated with starch-encapsulated semiochemical-insecticide granules were comparable to mortality observed in plots treated with a broadcast application of carbaryl (Sevin XLR Plus) while using 90\% less insecticide. Mortality of $D$. barbert Smith \& Lawrence was significantly greater in Sevin XLR Plus-treated plots than in plots treated with starch granules. Mortality of the coccinellid Coleomegilla maculata lengi Timberlake was significantly greater in plots treated with Sevin XLR Plus than in plots treated with starch granules, whereas a reverse trend was observed for the carabid Harpalus pennsylvanicus De Geer. Data suggest that efficacy of starch matrix delivery systems may be affected by the interaction of various biotic and abiotic factors but starch matrices appear to have potential as tools that could be used in the development of new, more environmentally sound, corn rootworm management programs.
\end{abstract}

KEY WORDS Insecta, corn rootworms, semiochemicals, starch matrices

The Genus Diabrotica Chevrolat includes many economically important species (Krysan \& Smith 1987). The western corn rootworm, $D$. virgifera virgifera LeConte, and northern corn rootworm, $D$. barberi Smith \& Lawrence, are widely distributed pests of field corn, Zea mays $\mathrm{L}$., in the midwest (Chiang 1973). The southern corn rootworm, $D$. undecimpunctata howardi Barber, has a broad host range (Arant 1929) and is an economic pest of peanuts, sweet potatoes, and corn in the southeastern United States (Hunt \& Baker 1982). Root feeding by larvae of these species can affect plant growth and reduce yield. It is estimated that control costs and crop losses due to Diabrotica spp. approach $\$ 1$ billion annually (Metcalf 1986).

The primary management tactic for Diabrotica spp. in continuous corn has been the use of insecticides. Typically, soil insecticides are applied at planting time or first cultivation to reduce larval numbers in the root zone (Mayo \& Peters 1978). As an alternative, broadcast insecticide applications may be used to suppress beetles in late summer, thus reducing oviposition and subsequent larval damage the following year (Pruess et al. 1974).
However, increased public pressure to protect the environment (i.e., nontarget organisms and ground water) and possible future legal constraints by governmental agencies on traditional pesticide use have resulted in an increased emphasis on the development of new, more environmentally sound corn rootworm management technology.

Semiochemicals have been used successfully to attract corn rootworm adults to baited traps (Lampman et al. 1987; Lampman \& Metcalf 1987, 1988; Lance 1988a; Meinke et al. 1989; Weissling et al. 1989) and to alter their spatial distribution (Lance 1988b). Results of small-plot field assays conducted by Metcalf et al. (1987) have shown that baits made from dried Cucurbita fruits or corn grits and impregnated with semiochemicals and insecticides could kill corn rootworm adults, thus demonstrating the potential that semiochemicalinsecticide combinations may have in future corn rootworm management programs. However, practical use of corn rootworm specific semiochemicalinsecticide mixtures has been impeded by the lack of viable delivery systems that release volatile active ingredients over time. 
Controlled release technology has been developed over the past $15 \mathrm{yr}$ in which starch is used to encapsulate pesticides. The starch matrix concept has been successfully used to develop controlledrelease herbicide (Schreiber et al. 1978, Baur 1980), insecticide (Trimnell et al. 1982), and Bacillus thuringiensis Berliner (Dunkle \& Shasha 1988) granular formulations.

We have been investigating the feasibility of using the starch matrix concept to create controlledrelease granular semiochemical-insecticide formulations. Initial studies have shown that $D$. $v$. virgifera sex pheromone (racemic [Meinke et al. 1989]) and selected plant-derived corn rootworm attractants (Weissling et al. 1989) could be successfully encapsulated in a starch-borate matrix. When formulations were placed in cornfields, starch-encapsulated semiochemicals were released over time from the matrix at levels that attracted corn rootworm adults.

This article presents the results of experiments designed to determine if starch-encapsulated semiochemical-insecticide formulations would attract and kill corn rootworm adults and if the efficacy of starch-encapsulated semiochemicalinsecticide formulations is comparable with a broadcast insecticide commonly used for adult corn rootworm control, and to determine the potential effects of starch-encapsulated formulations on selected nontarget species in field corn.

\section{Materials and Methods}

All field experiments were conducted at the University of Nebraska Agricultural Research and Development Center, near Mead, Nebr. On completion of field tests, all plants in plots receiving the experimental formulations were removed and destroyed.

Various compounds that have been identified as Diabrotica semiochemicals were used in the experimental starch formulations. The attractants that were used included the TIC mixture (a 1:1:1 mixture of 1,2,4-trimethoxybenzene, indole, and transcinnamaldehyde [Lampman \& Metcalf 1987]) or para-methoxycinnamonitrile (pMCN, Metcalf \& Lampman 1989). Semiochemicals were purchased from Aldrich Chemical Company, Inc., Milwaukee, Wis. Cucurbita foetidissima HBK root powder (contains cucurbitacins E, I, and E-glycoside; Metcalf et al. 1982) was added to formulations to induce Diabrotica feeding (Chambliss \& Jones 1966). C. foetidissima root powder from the same source was used in all experiments but cucurbitacin content was not quantified. However, Metcalf et al. (1982) have determined that the amount of cucurbitacin E, I, and E-glycoside in fresh C. foetidissima root was $0.28,1.72$, and $0.59 \mathrm{mg} / \mathrm{g}$, respectively. Pollen (C. C. Pollen Company, Scottsdale, Ariz.) was also added to formulations used in 1988 and 1989 as an additional feeding-gustatory stimulant (unpublished data). Insecticides used were carbaryl (Sevin XLR Plus, Union Carbide Agricultural Products, Research Triangle Park, N.C.), and technical formulations of carbaryl, methomyl, and carbofuran.

Experiment 1. A prototype starch-encapsulated semiochemical-insecticide formulation was developed to determine if a starch-based formulation would kill corn rootworm beetles in the field and to determine if beetle distribution and formulation efficacy would be significantly affected by application rate. The technique described by Weissling et al. (1989) was used to introduce semiochemicals and insecticide into a starch borate matrix (SBM; Trimnell et al. 1982) before gelatinization. Individual components of the TIC mixture were formulated at $1 \mathrm{mg} / \mathrm{g}$ SBM. Previous work with the SBM has shown that indole is lost during the formulation process, resulting in a TC mixture in the final matrix (Weissling et al. 1989). C. foetidissima root powder, and Sevin XLR Plus were formulated at $0.22 \mathrm{~g}$ and $1.5 \mathrm{mg}$ (AI)/g SBM, respectively. After drying, the SBM formulation was made into 20-30 mesh granules.

Four treatments (three rates of SBM granules: $1.14,11.4,114 \mathrm{~kg} / \mathrm{ha}$; untreated check) were evaluated in a 40-ha cornfield from 29-31 August 1987. Treatments were arranged in a randomized complete block design (four replications) with each block comprising four plots ( 7.6 by $7.6 \mathrm{~m}$ each) spaced $50 \mathrm{~m}$ apart. Blocks were also separated by $50 \mathrm{~m}$. The SBM formulation was hand applied to plots by sprinkling the appropriate amount of granules per unit area over the tops of plants. Plants at the time of application were in the dough stage [R4 (Ritchie \& Hanway 1984)].

To estimate adult corn rootworm populations in the test field and to document beetle distributional changes associated with SBM granule application, whole-plant beetle counts were taken before, and $24 \mathrm{~h}$ after application by quietly approaching 10 randomly selected plants per plot and counting all corn rootworm beetles on each plant (Tollefson 1986). In addition, efficacy of the SBM formulation was determined 24,48 , and $72 \mathrm{~h}$ following application by searching for and collecting all dead and moribund (dying) corn rootworm beetles on plants and on the ground $0.38 \mathrm{~m}$ to both sides of one row (5.8 $\mathrm{m}^{2}$ sampling area). The sampling area was randomly chosen within each plot before SBM application.

Experiment 2. Two starch matrices formulated with the same semiochemicals and various carbamate insecticides were presented to $D$. v. virgifera adults in laboratory bioassays to compare efficacy among matrices and insecticides. Carbamate insecticides were used because they have been shown to be effective Diabrotica stomach poisons (Metcalf et al. 1987). The technique described by Dunkle \& Shasha (1988) was used to incorporate semiochemicals and insecticides into a pH-neutral matrix made from pregelatinized corn starch (PGM). PGM and SBM formulations were compared in the 
experiment. Materials were added to each formulation before starch gelatinization occurred.

PGM and SBM insecticide treatments included: carbofuran, methomyl, and carbaryl, each formulated individually at $7.5-\mathrm{mg}$ technical material per $g$ matrix, or no insecticide. All treatments were formulated with $3 \mathrm{mg}$ ( $1 \mathrm{mg}$ each compound) TICmixture, $37.5 \mathrm{mg} \mathrm{C}$. foetidissima root powder, and $5 \mathrm{mg}$ pollen per $\mathrm{g}$ matrix. Unless otherwise stated, semiochemicals and insecticide were added to starch matrices at these rates in subsequent experiments. After drying, the starch formulations were made into 20-30 mesh granules.

Starch granules (100 mg per treatment per replication) were placed in glass Petri dishes ( 15 by $60 \mathrm{~mm}$ ), placed in the bottom of cylindrical plastic containers $\left(850 \mathrm{ml}^{3}\right)$. Each contained a watermoistened cotton wick and was enclosed with a plastic lid that had a $28-\mathrm{cm}^{2}$ circular vent covered with nylon mesh. Ten laboratory-reared, nondiapause strain D.v. virgifera adults (colony originally obtained from French Ag., Lamberton, Minn.) were introduced into each container. Containers were then arranged in a completely random design (three replications) and held at $23^{\circ} \mathrm{C}$, with a photoperiod of (L:D) 14:10. D. v. virgifera mortality was determined at $24 \mathrm{~h}$. This bioassay technique was used for all subsequent laboratory tests.

Experiment 3. PGM formulations containing $C$. foetidissima root powder, pollen, technical carbaryl, and either the TIC-mixture or pMCN were placed in Pherocon $1 C$ traps (Trece, Salinas, Calif.) from 6-22 August 1988 to evaluate PGM formulation efficacy in field corn. Treatments included: 1.12 g, 10-20 mesh PGM-TIC granules; 1.12 g 10 20 mesh PGM-pMCN granules; or an empty trap. Granules were placed in plastic Petri dish bottoms ( 15 by $100 \mathrm{~mm}$ ) taped to the bottoms of adhesive free traps. Petri dishes were taped to the bottom of control traps, but no granules were added. Traps were attached to plants at ear height.

Within a 40-ha field, treatments were arranged in a randomized complete block design (four replications) with each block (separated by $25 \mathrm{~m}$ ) consisting of three traps spaced $25 \mathrm{~m}$ apart. All dead or moribund $D$. $v$. virgifera and $D$. barberi beetles found in traps or on the ground directly below traps were collected daily for $16 \mathrm{~d}$ following application. Corn had just completed pollination at the beginning of the experiment (R2 stage [Ritchie \& Hanway 1984]).

Adult corn rootworm sex ratios were monitored in the field with 12 unbaited Pherocon AM Traps (Trece, Salinas, Calif. [three per block]) located $12.5 \mathrm{~m}$ away from any baited trap and attached to plants at ear height. Traps were replaced after $4,8,12$, and $16 \mathrm{~d}$. Beetles were counted and sex ratios were determined for each Diabrotica species from a subsample of up to 600 beetles ( 50 per trap) collected on each sample date. Whole plant beetle counts were taken four times during the experiment $(4,8,11$, and 16 August) on eight randomly selected plants near each of the four blocks to estimate population levels. Weathered PGM-TIC granules were collected from traps after $25 \mathrm{~d}$ and were presented to $D$. v. virgifera in a laboratory assay (as described in experiment 2) to determine if the formulation would still kill beetles. The PGMpMCN formulation was not evaluated.

Experiment 4a. PGM and SBM semiochemical-insecticide formulations and a commercially available insecticide commonly used for adult corn rootworm control were evaluated in a 4-ha cornfield from 15-21 August 1989. The objectives of this experiment were to determine the efficacy of each formulation as a corn rootworm adult control agent and to determine if selected nontarget insects are adversely affected by the formulations. The experimental design was identical to experiment 1 except that plots and blocks were separated by 23 m. Four treatments were evaluated: SBM granules formulated with carbofuran and PGM granules formulated with carbaryl (both were formulated with the TIC mixture, C. foetidissima root powder, and pollen); Sevin XLR Plus (1:4l, Sevin/water); and an untreated check. Starch-encapsulated treatments were applied to plots by sprinkling $130 \mathrm{~g}$ $(22.4 \mathrm{~kg} / \mathrm{ha} ; 0.168 \mathrm{~kg}$ [AI] $/ \mathrm{ha})$ of $10-20$ mesh granules evenly over the tops of plants by hand. Sevin XLR Plus was applied at $1.68 \mathrm{~kg}(\mathrm{AI}) / \mathrm{ha}$ with a $\mathrm{CO}_{2}$-pressurized hand sprayer with a 0.76 -m-wide spray boom. Plants at the time of application were milk stage (R3 [Ritchie \& Hanway 1984]).

Whole-plant beetle counts were used to estimate adult corn rootworm population density. Beetles on five random plants per plot were counted before, and 1, 3, and $6 \mathrm{~d}$ following application. Efficacy of treatments was determined daily for $7 \mathrm{~d}$ following insecticide application by searching for and collecting all dead or moribund $D$. v. virgifera, $D$. barberi, and $D$. $u$. howardi within subplots (on plants of two adjacent rows and on the ground between these rows, $5.8 \mathrm{~m}^{2}$ ). Sampling areas were randomly chosen before application of treatments.

The coccinellid Coleomegilla maculata lengi Timberlake, and the carabid Harpalus pennsylvanicus De Geer were selected as nontarget insects that were commonly found in the test field. Dead and moribund individuals were collected from sampling areas to determine possible adverse effects of insecticide applications.

Experiment 4b. To determine treatment efficacy following completion of the experiment, samples of each granule type, located at the soil surface (100 mg), and leaf tissue (12.6 $\mathrm{cm}^{2}$ disks) from plots treated with Sevin XLR Plus were collected after $7 \mathrm{~d}$ in the field. Laboratory bioassays using the samples and $D$. $v$. virgifera then were conducted. The bioassay technique used was identical to the procedure described in experiment 2 except that treatments were replicated four times.

Statistical Analyses. Data were subjected to square root transformation $(\sqrt{x+0.5})$ and were analyzed by analysis of variance using the Statis- 
Table 1. Mean number $D$. v. virgifera adults per plant ( \pm SEM) before and $1 \mathrm{~d}$ following application of starchborate semiochemical-insecticide granules, 1987

\begin{tabular}{ccc}
\hline $\begin{array}{c}\text { Application } \\
\text { rate } \\
(\mathrm{kg} / \mathrm{ha})\end{array}$ & Before application & $1 \mathrm{~d}$ After application \\
\hline 0.00 & $0.48 \pm 0.13 \mathrm{aA}$ & $0.50 \pm 0.12 \mathrm{aA}$ \\
1.14 & $0.55 \pm 0.12 \mathrm{aA}$ & $0.68 \pm 0.14 \mathrm{aA}$ \\
11.40 & $0.60 \pm 0.23 \mathrm{aA}$ & $1.10 \pm 0.19 \mathrm{aB}$ \\
114.00 & $0.55 \pm 0.10 \mathrm{aA}$ & $2.18 \pm 0.40 \mathrm{bB}$ \\
\hline
\end{tabular}

Semiochemical-insecticide granules were formulated with $1,2,4$ trimethoxybenzene, indole, trans-cinnamaldehyde, Sevin XLR Plus, and C. foetidissima root powder. Means within a sample period (column) followed by the same lowercase letter are not significantly different $(P<0.05$; least significant difference). Means within application rates (rows) followed by the same uppercase letter are not significantly different $(P<0.05$; least significant difference).

tical Analysis System ANOVA procedure (SAS Institute 1985). Untransformed means are presented in all tables and figures. Analyses were conducted for treatment effects over the entire experimental period (all experiments) and within collection periods (experiments 1, 3, 4a). Least significant difference tests (SAS Institute 1985) were used for mean separation where significant $(P<0.05)$ statistical differences occurred. Orthogonal contrasts (SAS Institute 1985) were used to compare mean D. $v$. virgifera mortality among starch formulations in experiment 2.

\section{Results}

Experiment 1. The analysis of whole plant beetle counts taken before and after granule application indicates that significant differences in $D$. $v$ virgifera population levels occurred among treatments $(F=9.9 ; \mathrm{df}=3,9 ; P<0.01)$, among sample periods $(F=18.1 ; \mathrm{df}=1,9 ; P<0.01)$, and that a significant treatment $\times$ sample period interaction occurred $(F=7.1, \mathrm{df}=3,9 ; P<0.01)$. There were no significant differences in $D$. $v$. virgifera population levels among treatments before SBM application (Table 1). Following application, the mean number of $D$. v. virgifera per plant appeared to increase with rate of SBM granule application (Table 1). However, the only treatment that was significantly different than the untreated check was the $114-\mathrm{kg} / \mathrm{ha}$ rate. Within-treatment analyses indicated that $D$. $v$. virgifera populations significantly increased in the $11.4-$ and $114-\mathrm{kg} / \mathrm{ha}$ plots $1 \mathrm{~d}$ after application.

Counts of dead and moribund beetles indicated that the SBM formulation killed adult $D$. v. virgifera in each treated plot over the 3-d period following application. However, only the $114-\mathrm{kg} /$ ha treatment was significantly different than the untreated check (Fig, 1).

Experiment 2. D. v. virgifera mortality due to ingestion of SBM and PGM granular formulations containing insecticides ranged from $40-100 \%$ after $24 \mathrm{~h}$ (Table 2). Orthogonal contrasts indicate that D. v. virgifera mortality was significantly higher

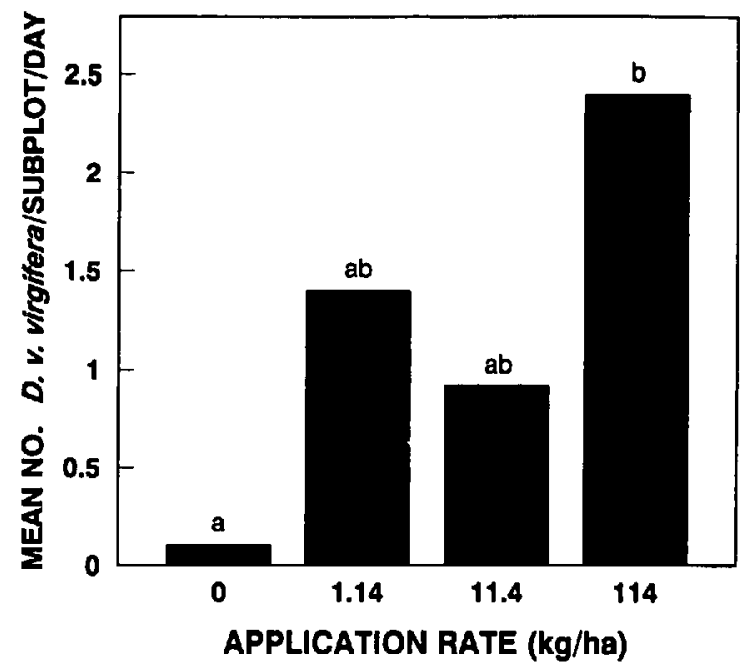

Fig. 1. Mean number of dead or moribund $D$. $v$. virgifera adults per subplot $\left(5.8 \mathrm{~m}^{2}\right)$ per day for $3 \mathrm{~d}$ following application of SBM granules formulated with 1,2,4-trimethoxybenzene, indole, trans-cinnamaldehyde, Sevin XLR Plus, and C. foetidissima root powder, 1987. Means followed by the same letter are not statistically different $(P<0.05$; least significant difference).

in PGM treatments formulated with carbaryl $(F=$ 10.8; $\mathrm{df}=1,14 ; P<0.01)$ and methomyl $(F=$ 71.4; $\mathrm{df}=1,14 ; P<0.01)$ than SBM treatments formulated with the same insecticides (Table 2). No D. v. virgifera mortality occurred in treatments without insecticide (Table 2), which indicated that the semiochemicals and matrix ingredients that were used would not kill beetles at the rates formulated.

Experiment 3. With the exception of one treatment (pMCN) within one sample period (sample period 2), the mean number of $D$. v. virgifera and $D$. barberi collected from traps containing PGM treatments declined with each successive sample period (Table 3 ). The D. v. virgifera population declined and the $D$. barberi population fluctuated at low levels during the test period (Table 4). This is reflected in the overall analysis because signifi-

Table 2. Mean percentage mortality of nondiapause strain $D$. v. virgifera adults ( \pm SEM) presented with SBM and PGM matrices formulated with and without carbamate insecticides

\begin{tabular}{lrc}
\hline Insecticide & SBM & PGM \\
\hline Carbofuran & $100.0 \pm 0.0$ & $100.0 \pm 0.0$ \\
Carbaryl & $66.7 \pm 6.7$ & $90.0 \pm 5.8^{a}$ \\
Methomyl & $40.0 \pm 10.0$ & $100.0 \pm 0.0^{a}$ \\
No insecticide & $0.0 \pm 0.0$ & $0.0 \pm 0.0$ \\
\hline
\end{tabular}

Both starch matrices are formulated with 1,2,4-trimethoxybenzene, indole, trans-cinnamaldehyde, $C$. foetidissima root powder, and pollen. $n=30$ ( 10 beetles per replication, three replications), 24-h bioassay.

a Significantly different at $P \leq 0.05$. Values were determined by orthogonal contrasts between starch matrices formulated with the same insecticide. 
Table 3. Mean number dead or moribund $D$. v. virgifera and $D$. barberi collected per day per sample period ( \pm SEM) at Pherocon IC traps baited with pregelatinized starch granules formulated with semiochemicals and carbaryl, 1988

\begin{tabular}{|c|c|c|c|c|c|c|c|c|}
\hline \multirow{3}{*}{ Treatment } & \multicolumn{8}{|c|}{ Sample period ${ }^{a}$} \\
\hline & \multicolumn{2}{|l|}{1} & \multicolumn{2}{|c|}{2} & \multicolumn{2}{|c|}{3} & \multicolumn{2}{|c|}{4} \\
\hline & I $\pm \mathrm{SEM}$ & $\begin{array}{c}\text { 9:8 } \\
\text { Ratio }\end{array}$ & $x \pm$ SEM & $\begin{array}{c}\text { 9:8 } \\
\text { Ratio }\end{array}$ & $\bar{x} \pm \mathrm{SEM}$ & $\begin{array}{c}9: 8 \\
\text { Ratio }\end{array}$ & $\bar{x} \pm \mathrm{SEM}$ & $\begin{array}{c}\text { Q:ठ } \\
\text { Ratio }\end{array}$ \\
\hline \multicolumn{9}{|c|}{ D. v. virgifera } \\
\hline $\begin{array}{l}\text { TIC mixture } \\
\text { pMCN } \\
\text { Check }\end{array}$ & $\begin{array}{l}8.5 \pm 1.1 \mathrm{a} \\
7.9 \pm 1.2 \mathrm{a} \\
0.0 \pm 0.0 \mathrm{~b}\end{array}$ & $\begin{array}{c}7.0 \\
5.0 \\
-\end{array}$ & $\begin{array}{r}4.3 \pm 0.9 \mathrm{~b} \\
10.8 \pm 2.6 \mathrm{a} \\
0.0 \pm 0.0 \mathrm{~b}\end{array}$ & $\begin{array}{l}3.0 \\
4.5 \\
-\end{array}$ & $\begin{array}{l}1.1 \pm 0.3 b \\
3.5 \pm 1.1 \mathrm{a} \\
0.0 \pm 0.0 \mathrm{~b}\end{array}$ & $\begin{array}{r}16.0 \\
5.2 \\
-\end{array}$ & $\begin{array}{l}0.4 \pm 0.2 \mathrm{ab} \\
0.8 \pm 0.3 \mathrm{a} \\
0.0 \pm 0.0 \mathrm{~b}\end{array}$ & $\begin{array}{r}2.0 \\
12.5 \\
-\end{array}$ \\
\hline \multicolumn{9}{|c|}{ D. barberi } \\
\hline $\begin{array}{l}\text { TIC mixture } \\
\text { pMCN } \\
\text { Check }\end{array}$ & $\begin{array}{l}1.8 \pm 0.4 a \\
1.5 \pm 0.5 a \\
0.0 \pm 0.0 b\end{array}$ & $\begin{array}{c}0.04 \\
0.09 \\
-\end{array}$ & $\begin{array}{l}1.6 \pm 0.5 \mathrm{a} \\
0.8 \pm 0.3 \mathrm{ab} \\
0.0 \pm 0.0 \mathrm{~b}\end{array}$ & $\begin{array}{c}0.04 \\
\text { All o } \\
-\end{array}$ & $\begin{array}{l}0.3 \pm 0.2 a \\
0.3 \pm 0.1 \mathrm{a} \\
0.0 \pm 0.0 \mathrm{a}\end{array}$ & $\begin{array}{c}\text { All o } \\
0.24 \\
-\end{array}$ & $\begin{array}{l}0.1 \pm 0.1 \mathrm{a} \\
0.1 \pm 0.1 \mathrm{a} \\
0.0 \pm 0.0 \mathrm{a}\end{array}$ & $\begin{array}{l}\text { All : } \\
\text { All : } \\
-\end{array}$ \\
\hline
\end{tabular}

Pregelatinized starch granules were formulated with C. foetidissima root powder $(37.5 \mathrm{mg} / \mathrm{g})$, pollen $(5 \mathrm{mg} / \mathrm{g})$, technical carbaryl $(7.5 \mathrm{mg} / \mathrm{g})$, and either a mixture of 1,2,4-trimethoxybenzene, indole, and trans-cinnamaldehyde (TIC mixture) each at $1 \mathrm{mg} / \mathrm{g}$, or para-methoxycinnamonitrile (pMCN) at $3 \mathrm{mg} / \mathrm{g}$. Means within a species and sample period followed by the same letter are not significantly different $(P<0.05$; least significant difference).

a Sample period $1=7-10$ August, $2=11-14$ August, $3=15-18$ August, $4=19-22$ August.

b Q:ठ Ratio: mean number dead female corn rootworms per dead male corn rootworms collected from Pherocon $1 \mathrm{C}$ traps.

cant differences occurred among treatments $(D . v$. virgifera: $F=18.6, \mathrm{df}=2,6 ; P<0.01$. D. barberi. $F=7.0 ; \mathrm{df}=2,6 ; P<0.03)$ and among sample periods (D. v. virgifera: $F=22.2$; $\mathrm{df}=3,162 ; P$ $<0.01$. D. barberi: $F=13.0 ; \mathrm{df}=3,162 ; P<0.01$ ). Significant sample period $\times$ treatment interactions were also observed (D. v. virgifera: $F=8.4$; $\mathrm{df}=$ 6,$162 ; P<0.01$. D. barberi: $F=4.0 ; \mathrm{df}=6,162$; $P<0.01$ )

Analyses of treatments within sample periods indicate that significantly more $D$. v. virgifera were collected from TIC-baited traps (sample period 1) and pMCN-baited traps (sample periods $1-4$ ) than from unbaited traps (Table 3). Significantly more $D$. v. virgifera were collected from pMCN-than TIC-baited traps during sample periods 2 and 3 . Significantly more $D$. barberi were collected from TIC- and pMCN-baited than unbaited traps during sample period 1 . Traps baited with the TIC mixture caught significantly more $D$. barberi than unbaited traps during sample period 2 (Table 3 ).

Table 4. D. v. virgifera and $D$. barberi populations and sex ratios during experiment 3,1988

\begin{tabular}{|c|c|c|c|c|c|c|}
\hline \multirow[b]{2}{*}{ Date } & \multicolumn{3}{|c|}{ D. v. virgifera } & \multicolumn{3}{|c|}{ D. barberi } \\
\hline & $\begin{array}{l}\text { No. per } \\
\text { plant } \\
\pm \text { SEM }\end{array}$ & $\begin{array}{c}\text { 8:d } \\
\text { Ratio }\end{array}$ & $\begin{array}{c}\vec{I} \\
\text { No. } \\
\text { per } \\
\text { trap }\end{array}$ & $\begin{array}{l}\text { No. per } \\
\text { plant } \\
\pm S E M\end{array}$ & $\begin{array}{c}\text { P:t } \\
\text { Ratio }\end{array}$ & $\begin{array}{c}x \\
\text { No. } \\
\text { per } \\
\text { trap }\end{array}$ \\
\hline 4 Aug. & $2.4 \pm 0.2$ & 0.54 & 236 & $0.5 \pm 0.1$ & 0.04 & 56 \\
\hline 8 Aug. & $1.9 \pm 0.3$ & 0.88 & 180 & $0.2 \pm 0.1$ & 0.13 & 25 \\
\hline 12 Aug. & $1.4 \pm 0.2$ & 1.01 & 149 & $1.0 \pm 0.2$ & 0.06 & 50 \\
\hline 16 Aug. & $1.3 \pm 0.2$ & 2.21 & 64 & $0.4 \pm 0.1$ & 0.04 & 23 \\
\hline 20 Aug. & $-\quad-$ & 4.03 & 25 & $-\quad-$ & 0.07 & 27 \\
\hline
\end{tabular}

9:\& Ratio: mean number dead female corn rootworms per dead male corn rootworms, determined from a subsample of up to 600 beetles ( 50 per trap) collected from unbaited Pherocon AM traps.
The $D . v$. virgifera female-male ratio in traps varied among treatments and sample periods, but females were always more numerous than males (Table 3). The trend was reversed for $D$. barberi as more males were killed in baited traps than females in most sample periods. This trend is somewhat reflected in the beetle population estimates as the female-male sex ratio increased over time for $D$. v. virgifera and remained low for D. barberi (Table 4).

Laboratory bioassays indicated that mortality of D. v. virgifera due to ingestion of weathered PGMTIC granules was significantly greater than mortality in the untreated check (mean percent mortality at $24 \mathrm{~h}[ \pm \mathrm{SEM}]: \mathrm{TIC}=70.0[ \pm 0.0]$, check $=$ $0.0[ \pm 0.0] ; n=30$ beetles per treatment)

Experiment 4a. The two starch-based formulations were as effective as Sevin XLR Plus at killing D. v. virgifera adults in treated plots (Fig. 2A), while greatly reducing the amount of insecticide used per hectare (SBM and PGM granules, 167.8 g; Sevin XLR Plus, 1,680 g [AI]/ha). The only rainfall received during the experimental period was on 18 August $(2.8 \mathrm{~cm})$.

$D$. v. virgifera population densities decreased in all plots during the experimental period (Table 5). However, population levels in insecticide-treated plots were significantly less than in untreated plots 1 and $3 \mathrm{~d}$ following application. There were no differences in $D$. v. virgifera population levels among treatments $6 \mathrm{~d}$ after insecticide application. $D$. barberi and D. u. howardi population levels were low ( $<0.3$ per plant) and varied throughout all sample periods.

The analysis conducted on mortality of each species over the entire experiment indicates that significant differences occurred among treatments $(D$. v. virgifera: $F=8.7 ; \mathrm{df}=3,9 ; P<0.01$. D. barberi: 


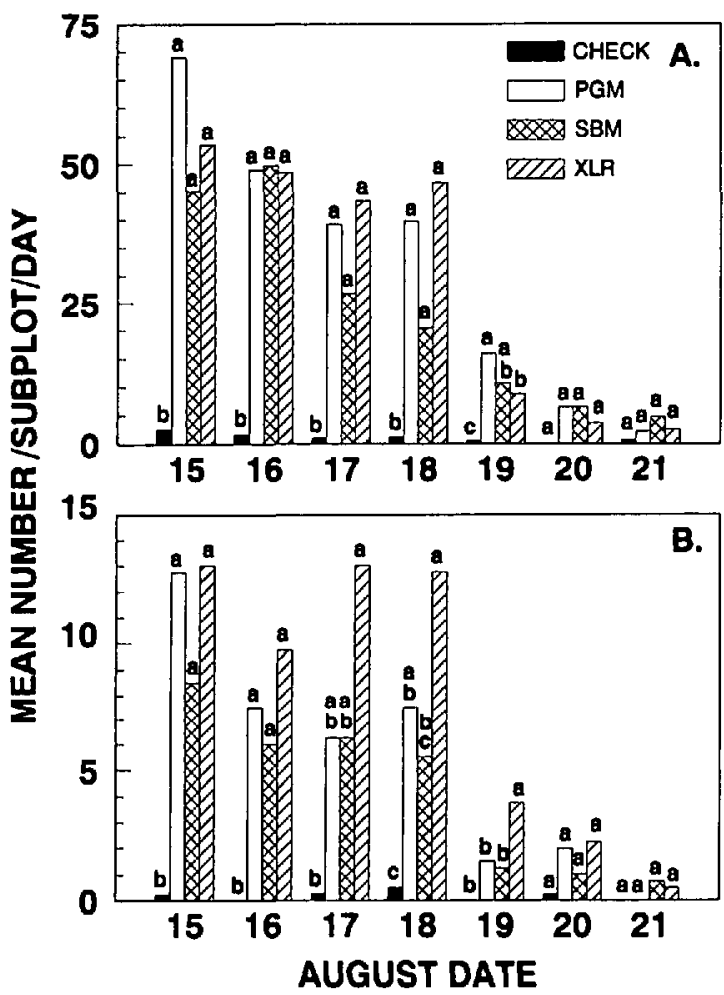

Fig. 2. Mean number of dead or moribund $D$. $v$. virgifera (A) and $D$. barberi (B) collected per subplot $\left(5.8 \mathrm{~m}^{2}\right)$ per day for $7 \mathrm{~d}$ from untreated plots, and plots treated with Sevin XLR Plus, and PGM and SBM granules formulated with 1,2,4-trimethoxybenzene, indole, trans-cinnamaldehyde, $C$. foetidissima root powder, and pollen. SBM and PGM granules were formulated with carbofuran and carbaryl, respectively, and applied 14 August 1989. Means followed by the same letter within a sample date are not statistically different $(P<0.05$; least significant difference).

$F=11.1 ; \mathrm{df}=3,9 ; P<0.01 . D$. u. howardi: $F=$ 7.6; $\mathrm{df}=3,9 ; P<0.01$. C. $m$. lengi: $F=47.5 ; \mathrm{df}$ $=3,9 ; P<0.01$. H. pennsylvanicus: $F=11.3 ; \mathrm{df}$ $=3,9 ; P<0.01)$ and among sample periods $(D$. v. virgifera: $F=27.3 ; \mathrm{df}=6,54 ; P<0.01$. $D$ barberi: $F=24.8$; $\mathrm{df}=6,54 ; P<0.01 . D$. u. howardi: $F=2.4 ; \mathrm{df}=6,54 ; P<0.04$. C. m. lengi: $F=12.4 ; \mathrm{df}=6,54 ; P<0.01$. H. pennsylvanicus:
$F=2.5 ; \mathrm{df}=6,54 ; P<0.04)$. A significant treatment $\times$ sample period interaction was observed for all species except $D . u$. howardi and $H$. pennsylvanicus (D. v. virgifera: $F=3.6, \mathrm{df}=18,54, P$ $<0.01$. D. barberi: $F=3.7 ; \mathrm{df}=18,54 ; P<0.01$. C. $m$. lengi: $F=5.9 ; \mathrm{df}=18,54 ; P<0.01$ ).

Analyses of treatments within sample periods indicate that significantly more dead or moribund $D$. v. virgifera (Fig. 2A) and D. barberi (Fig. 2B) were collected from one or more insecticide treated than untreated plots for at least $5 \mathrm{~d}$. There were no significant differences in $D$. v. virgifera mortality among insecticide treatments except for the fifth sampling period (19 August), when mortality in the PGM treatment was significantly greater than mortality in the Sevin XLR Plus treatment. There were also no significant differences in $D$. barberi mortality among insecticide treatments during the first three sampling periods (15-17 August). However, Sevin XLR Plus killed significantly more $D$. barberi than the SBM treatment 4 and 5 d following application. $D$. barberi mortality in Sevin XLR Plus treated plots was also significantly greater than mortality in PGM treated plots $5 \mathrm{~d}$ after application. More males of each species were killed than females during the experiment (Table 6).

Significantly more dead and moribund $D . u$. howardi, C. m. lengi, and H. pennsylvanicus were collected from one or more of the insecticide treatments than the untreated check (Table 7). Mortality of $D$. u. howardi and $H$. pennsylvanicus was also significantly higher in PGM than Sevin XLR Plus treated plots (Table 7). Significantly more dead C. $m$. lengi were collected from Sevin XLR Plus treated plots than any other treatment. Trends were consistent through all sample periods.

Experiment 4b. Results of laboratory bioassays using aged SBM, and PGM granules, and leaf tissue from Sevin XLR Plus treated plots indicate that PGM and SBM granules remained relatively toxic to $D$. v. virgifera beetles, whereas leaf tissues treated $7 \mathrm{~d}$ before with Sevin XLR Plus resulted in no mortality. D. v. virgifera mortality due to ingestion of SBM and PGM granules was significantly greater than the untreated check and leaf tissues; mean percent mortality at $24 \mathrm{~h}$ ( \pm SEM): SBM granules $=53( \pm 15.5) ;$ PGM granules $=88( \pm 4.8)$; leaf tissue

Table 5. Mean number $D$. v. virgifera per plant ( \pm SEM) before, and 1,3 , and $6 \mathrm{~d}$ following application of starchhased formulations or Sevin XLR Plus, 1989

\begin{tabular}{lcccc}
\hline \hline \multirow{2}{*}{ Treatment } & \multicolumn{4}{c}{ Sample period (d following application) } \\
\cline { 2 - 4 } & 0 & 1 & 3 & 6 \\
\hline Untreated & $2.1 \pm 0.4 \mathrm{aA}$ & $1.3 \pm 0.4 \mathrm{aB}$ & $1.0 \pm 0.2 \mathrm{aB}$ & $1.0 \pm 0.2 \mathrm{aB}$ \\
PGM & $1.8 \pm 0.3 \mathrm{aA}$ & $0.5 \pm 0.1 \mathrm{bB}$ & $0.6 \pm 0.2 \mathrm{bB}$ & $1.0 \pm 0.2 \mathrm{aB}$ \\
SBM & $1.3 \pm 0.2 \mathrm{aA}$ & $0.4 \pm 0.1 \mathrm{bC}$ & $0.5 \pm 0.2 \mathrm{bBC}$ & $1.0 \pm 0.3 \mathrm{aAB}$ \\
Sevin XLR & $2.6 \pm 0.3 \mathrm{aA}$ & $0.5 \pm 0.1 \mathrm{bB}$ & $0.4 \pm 0.2 \mathrm{bB}$ & $1.0 \pm 0.3 \mathrm{aB}$ \\
\hline
\end{tabular}

SBM and PGM granules formulated with 1,2,4-trimethoxybenzene, indole, trans-cinnamaldehyde, C. foetidissima root powder, and pollen. SBM and PGM granules were formulated with carbofuran and carbaryl, respectively. Means within a sample period (column) followed by the same lowercase letter are not significantly different $(P<0.05$; least significant difference). Means within a treatment (row) followed by the same uppercase letter are not significantly different $(P<0.05$; least significant difference). 
Table 6. Female-male sex ratio of dead $D$. v. virgifera, $D$. barberi, and $D$. $u$. howardi collected from plots treated with starch-based semiochemical-insecticide formulations or Sevin XLR Plus, 1989

\begin{tabular}{|c|c|c|c|}
\hline Treatment & \multicolumn{3}{|c|}{ \&:ठ Ratio I SEM (n) } \\
\hline $\begin{array}{l}\text { Untreated } \\
\text { PGM } \\
\text { SBM } \\
\text { Sevin XLR Plus }\end{array}$ & $\begin{array}{l}1.46 \pm 0.46(32) \\
0.53 \pm 0.02(887) \\
0.85 \pm 0.31(657) \\
0.54 \pm 0.08(829)\end{array}$ & $\begin{array}{l}0.67 \pm 0.50 \\
0.17 \pm 0.16(150) \\
0.22 \pm 0.12(117) \\
0.54 \pm 0.22(220)\end{array}$ & $\begin{array}{l}-\overline{0}-\overline{0}(0) \\
0.09 \pm 0.07(49) \\
0.22 \pm 0.13(33) \\
0.39 \pm 0.23(25)\end{array}$ \\
\hline
\end{tabular}

SBM and PGM granules formulated with 1,2,4-trimethoxybenzene, indole, trans-cinnamaldehyde, C. foetidissima root powder, and pollen. SBM and PGM granules were formulated with carbofuran and carbaryl, respectively.

(Sevin XLR Plus) $=0.0( \pm 0.0)$; untreated check $=$ $0.0( \pm 0.0)(n=40$ beetles per treatment $)$.

\section{Discussion}

The response of $D$. v. virgifera to attractants released from the field-applied SBM formulation resulted in a concentration of the population in treated plots, which appeared to be dependent on application rate (experiment 1). This suggests that plant-derived semiochemicals could be used to manipulate the distributions of $D$. v. virgifera populations by attracting beetles into portions of corn fields treated with starch-based baits. Lance (1988b) presents data demonstrating that adult corn rootworm distributions can be influenced by pheromonal attractants in field corn. Also, Lampman \& Metcalf (1987) make reference to unpublished data suggesting that plant-derived attractants may be used to concentrate beetles at field plot borders.

Although significant $D$. v. virgifera mortality was observed in plots receiving SBM granules in experiment 1 , mortality levels were not high enough to provide adequate corn rootworm control. This was somewhat surprising because a large number of adult $D$. $v$. virgifera were observed feeding on SBM granules following application (personal observation). Low $D$. v. virgifera mortality levels may have been caused by a partial loss of carbaryl during the formulation process. During SBM formulation, compounds incorporated into the matrix are

Table 7. Mean number of dead or moribund $D$. undecimpunctata howardi, C. $m$. lengi, and $H$. pennsylvanicus collected per subplot $\left(5.8 \mathrm{~m}^{2}\right)$ per day ( \pm SEM) for $7 \mathrm{~d}$ following application of starch-based semiochemicalinsecticide formulations or Sevin XLR Plus, 1989

\begin{tabular}{llcc}
\hline \hline \multicolumn{1}{c}{ Treatment } & D. u. howardi & C. m. lengt & $\begin{array}{c}\text { H. pennsyl- } \\
\text { vanicus }\end{array}$ \\
\hline Untreated & $0.0 \pm 0.0 \mathrm{c}$ & $0.0 \pm 0.0 \mathrm{c}$ & $0.0 \pm 0.0 \mathrm{c}$ \\
PGM & $1.8 \pm 0.3 \mathrm{a}$ & $2.9 \pm 0.5 \mathrm{~b}$ & $2.4 \pm 0.4 \mathrm{a}$ \\
SBM & $1.2 \pm 0.2 \mathrm{ab}$ & $2.3 \pm 0.4 \mathrm{~b}$ & $1.1 \pm 0.2 \mathrm{~b}$ \\
Sevin XLR Plus & $0.9 \pm 0.2 \mathrm{~b}$ & $12.2 \pm 1.4 \mathrm{a}$ & $0.3 \pm 0.1 \mathrm{c}$ \\
\hline
\end{tabular}

SBM and PGM granules formulated with 1,2,4-trimethoxybenzene, indole, trans-cinnamaldehyde, $C$. foetidissima root powder, and pollen. SBM and PGM granules were formulated with carbofuran and carbaryl, respectively. Means within species followed by the same letter are not statistically different $(P<0.05$; least significant difference). exposed to a high $\mathrm{pH}$ environment. In an alkaline environment, carbaryl hydrolyzes to l-naphthol, and methomyl and carbofuran readily degrade (Worthington \& Walker 1983). Assay results from experiment 2 (Table 2) provide supportive evidence suggesting that the SBM environment is not as compatible with some carbamate insecticides as the PGM environment is.

Carbofuran was the only carbamate evaluated that effectively killed $D$. $v$. virgifera when formulated into the SBM (Table 2). When SBM granules formulated with carbofuran were evaluated in the field (experiment $4 \mathrm{a}$ ), resulting $D . v$. virgifera mortality was similar to mortality levels obtained with PGM formulations that contained carbaryl. However, efficacy of SBM granules declined somewhat faster than PGM granules (experiments $4 \mathrm{a}$ and $4 \mathrm{~b}$ ), which may have been a function of attractant release rates or the initial encapsulation rate of carbofuran.

Habitat and feeding preferences of the coccinellid C. $m$. lengi and the carabid $H$. pennsylvanicus may have interacted with insecticide placement resulting in the different mortality trends observed between treatments in experiment $4 \mathrm{a}$ (Table 7). C. $m$. lengi were found primarily on corn foliage, whereas $H$. pennsylvanicus were observed only on the ground. The contact insecticide Sevin XLR Plus was primarily directed at the corn canopy while starch-based granules lodged on the plants and fell to the ground during application. C. $m$. lengi may have had a greater chance of coming in contact with a Sevin XLR Plus coated leaf than encountering and ingesting a starch granule. The omnivorous $H$. pennsylvanicus had available starch granules and Diabrotica beetles killed by insecticide treatments as potential food sources on the ground. In laboratory no-choice tests, $C . m$. lengi and $H$. pennsylvanicus fed on starch-based granules which resulted in beetle mortality; however, most $H$. pennsylvanicus individuals were unaffected by feeding on $D$. $v$. virgifera killed by starch granules (unpublished data). This suggests that the observed mortality trends for H. pennsylvanicus may have been primarily due to feeding directly on the starch-based granules.

The interaction of environmental conditions, $D i$ abrotica beetle behavior, and starch granule behavior (i.e., degradation rates, release rates, etc.) 
may have contributed to variable formulation efficacy and the significant treatment $\times$ sample period interactions observed in all field experiments.

Decreased mortality of $D$. v. virgifera observed near the end of experiment 3 may have partially been a result of diminishing field populations. Because the PGM-TIC granules effectively killed $D$. v. virgifera in postexperiment laboratory bioassays, this suggests that acceptable cucurbitacin and insecticide levels were present in the granules throughout the experiment. No chemical analyses of granules were conducted so it is not known if TIC or pMCN levels were adequate to effectively attract beetles to the traps during sample periods 3 and 4.

Rainfall received during experiment $4 a$ washed most of the starch granules remaining on plants onto the ground, which was followed by a sharp decline in corn rootworm mortality. However, granules collected from plots still effectively killed D. v. virgifera in laboratory bioassays (experiment 4b). When on the ground, granules may become physically unavailable to corn rootworm beetles (i.e., fall into soil cracks or be covered with soil) or the interaction of granule physical properties (i.e., semiochemical plume pattern, degradation rates, etc.) and beetle behavior at ground level may not lead to many beetle-granule encounters. Related field study results indicate that corn rootworm mortality is substantially higher in traps baited with starch granules at ear height than in traps placed at ground level (unpublished data).

The starch-encapsulated formulations evaluated in experiment 4a effectively killed and reduced populations of adult $D$. v. virgifera, comparing favorably with a commercially available insecticide. However, these specific formulations may not have quite as much potential for management of $D$. barberi. Because the test plot size used in experiment 4 a was relatively small and the $D$. v. virgifera population in corn surrounding the plots was high (good immigration potential), the level and duration of beetle suppression is difficult to evaluate. To determine if a semiochemical-insecticide adult corn rootworm management approach will be effective (i.e., suppression of females to reduce egg laying and prevent subsequent economic damage the following season), large scale field evaluations are needed to address potential beetle immigration effects on formulation efficacy.

Data reported in this paper suggest that the starch delivery system may have potential as a tool that could be used in the development of new, more environmentally sound corn rootworm management programs. The use of starch-encapsulated semiochemical-insecticide formulations for adult $D$. v. virgifera management could potentially reduce the amount of insecticide that is applied to corn production systems and may be less harmful to certain nontarget organisms. The starch matrix delivery system may also be applicable to other insect management situations where semiochemi- cals are being used. Additional research is needed to optimize the semiochemical mixture that is needed to produce effective formulations, and to address the various biotic and abiotic factors that interact to affect formulation efficacy.

\section{Acknowledgment}

We thank David Marx for statistical consultation, and Mike Barnhart, Jim Brown, Rod Hansen, Kandy Lytle, Greg Grundmayer, and Troy Urban for laboratory and field assistance.

This research was supported by the Nebraska Corn Development, Utilization, and Marketing Board, and the University of Nebraska Agricultural Experimental Station, Project 17-043.

This article is 9164 of the journal series of the Nebraska Agricultural Research Division and contribution 730 of the Department of Entomology, University of NebraskaLincoln.

\section{References Cited}

Arant, F. S. 1929. Biology and control of the southern corn rootworm. Alabama Polytechnical Institute Agricultural Bulletin 230.

Baur, J. R. 1980 . Release characteristics of starch xanthide herbicide formulations. J. Environ. Qual. 9: 379-382.

Chambliss, O. L. \& C. M. Jones. 1966. Cucurbitacins: specific insect attractants in Cucurbitaceae. Science 153: 1392-1393.

Chiang, H. C. 1973. Bionomics of northern and western corn rootworms. Ann. Rev. Entomol. 18: 47-72.

Dunkle, R. L. \& B. S. Shasha. 1988. Starch-encapsulated Bacillus thuringiensis: a potential new method for increasing environmental stability of entomopathogens. Environ. Entomol. 17: 120-126.

Hunt, T. N. \& J. R. Baker. 1982 . Insects and related pests of field crops: some important, common and potential pests in North Carolina. North Carolina Agricultural Extension Service Manual 271.

Krysan, J. L. \& R. F. Smith. 1987. Systematics of the virgifera species group of Diabrotica (Coleoptera: Chrysomelidae: Galerucinae). Entomography 5: 375484.

Lampman, R. L. \& R. L. Metcalf. 1987. Multicomponent kairomonal lures for southern and western corn rootworms (Coleoptera: Chrysomelidae: Diabrotica spp.). J. Econ. Entomol. 80: 1137-1142.

1988. The comparative response of Dtabrotica species (Coleoptera: Chrysomelidae) to volatile attractants. Environ. Entomol. 17: 644-648.

Lampman, R. L., R. L. Metcalf \& J. F. Andersen. 1987. Semiochemical attractants of Diabrotica undecimpunctata howardi Barber, the southern corn rootworm, and Diabrotica virgifera virgifera LeConte, the western corn rootworm (Coleoptera: Chrysomelidae). J. Chem. Ecol. 13: 959-975.

Lance, D. R. 1988a. Potential of 8-methyl-2-decyl propanoate and plant-derived volatiles for attracting corn rootworm beetles (Coleoptera: Chrysomelidae) to toxic baits. J. Econ. Entomol. 81: 1359-1362.

1988b. Responses of northern and western corn rootworms to semiochemical attractants in corn fields. J. Chem. Ecol. 14: 1177-1185.

Mayo, Z B \& L. L. Peters. 1978. Planting vs. cul- 
tivation time applications of granular soil insecticides to control larvae of corn rootworms in Nebraska. J. Econ. Entomol. 71: 801-803.

Meinke, L. J., Z B Mayo \& T. J. Weissling. 1989. A pheromone delivery system: western corn rootworm (Coleoptera: Chrysomelidae) pheromone encapsulation in a starch borate matrix. J. Econ. Entomol. 82: 1830-1835.

Metcalf, R. L. 1986. Foreword, pp. vii-xv. In J. L. Krysan \& T. A. Miller [eds.], Methods for the study of pest Diabrotica. Springer, New York.

Metcalf, R. L. \& R. L. Lampman. 1989. Estragole analogs as attractants for corn rootworms (Coleoptera: Chrysomelidae). J. Econ. Entomol. 82: 123-129.

Metcalf, R. L., A. M. Rhodes, R. A. Metcalf, J. Ferguson, E. R. Metcalf \& P. Y. Lu. 1982. Cucurbitacin contents and Diabroticite (Coleoptera: Chrysomelidae) feeding upon Cucurbita spp. Environ. Entomol. 11: 931-937.

Metcalf, R. L., J. E. Ferguson, R. Lampman \& J. E. Andersen. 1987. Dry cucurbitacin-containing baits for controlling Diabroticite beetles (Coleoptera: Chrysomelidae). J. Econ. Entomol. 80: 870-875.

Pruess, K. P., J. F. Witkowski \& E. S. Raun. 1974. Population suppression of western corn rootworms by adult control with ULV malathion. J. Econ. Entomol. 67: 651-655.

Ritchie, S. W. \& J. J. Hanway. 1984. How a corn plant develops. Iowa State University Cooperative Extension Service Special Report 48.

SAS Institute Inc. 1985. SAS users' guide: statistics, version 5 ed. SAS Institute, Cary, N.C.

Schreiber, M. M., B. S. Shasha, M. A. Foss, P. L. Orwick \& D. W. Edgecomb. 1978. Efficacy and rate of release of EPTC and butylate from starch encapsulated formulations under greenhouse conditions. Weed Sci. 26: 679-686.

Tollefson, J. J. 1986. Field sampling of adult populations, pp. 123-146. In J. L. Krysan \& T. A. Miller [eds.], Methods for the study of pest Diabrotica. Springer, New York.

Trimnell, D., B. S. Shasha, R. E. Wing \& F. H. Otey. 1982. Pesticide encapsulation using a starch-borate complex as wall material. J. Appl. Polym. Sci. 27: 3919-3928.

Weissling, T. J., L. J. Meinke, D. Trimnell \& K. L. Golden. 1989. Behavioral responses of Diabrotica adults to plant-derived semiochemicals encapsulated in a starch borate matrix. Entomol. Exp. Appl. 53: 219-228.

Worthington, C. R. \& S. B. Walker [eds]. 1983. The pesticide manual: a world compendium. Lavenham Press, Lavenham, Suffolk, Great Britain.

Received for publication 15 March 1990; accepted 11 September 1990. 